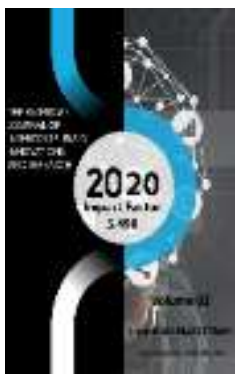

Journal Website: http://usajournalshub.c om/index,php/tajiir

Copyright: Original content from this work may be used under the terms of the creative commons attributes 4.0 licence.

\section{Media Development Of Lawyers As The Tool Of Media Competence}

\author{
Taylakova Shaxnoza Norbekovna \\ PhD Chairman Of Department Of "Digital Media And Internet" Of University Of Journalism \\ And Mass Communication Of The Republic Of Uzbekistan, Tashkent, Uzbekistan \\ Kamoliddin Tursunpulatovich Beknazarov \\ PhD Doctoral Student, University Of Journalism And Mass Communications Of The Republic \\ Of Uzbekistan
}

\title{
ABSTRACT
}

The article reveals the essence of the concepts of "Information and communication space" and "communicative potential" even only professionally make sense only in a society that acquires the features of the created information society, which is the heir to the postindustrial era.

\section{KEYWORDS}

Media, Social Networks, Media Competence, Internet technology.

\section{INTRODUCTION}

The information society, the noospheric civilization, the information space, cyberspace, the information environment, virtual reality these words have become familiar not only in the pages of scientific and popular publications, but also in everyday speech. Mass consciousness strongly links these terms with computers and telecommunications. At the same time, computers and communications have at their disposal vocabulary and conceptual tools of the existential plan - they travel on the Internet, enter it, live in it. Writers and filmmakers, who have long been fond of this topic, regularly throw out another clone of the Lawnmower on the market. Programmer slang, and behind it the logical constructs of clearly "machine" origin, are increasingly being introduced into everyday life. There are new 
areas of artistic creativity and new genres related to computer technology, such as computer games, computer animations, which force us to recognize the fact of the birth of a special computer aesthetics and, perhaps, the formation of a virtual culture in general.

Philosophers, economists and political scientists talk about the transition to the information society, which should replace the post-industrial. This puts informational content on a par with the concepts of a global sociopolitical and economic plan.

It makes us treat computers and networks not only as technical achievements and means of simplifying the life of modern man, but also as distinctive beings that open up other life worlds to humanity.

Something similar happens with the perception of time - its marks, allowing to see the events in their sequence, the virtual computer environment as if erases and confuses. Information about the events of the past, stored on the Internet, is very different from the one we can get, flipping through the yellowed newspaper pages. Actualization of the past is carried out by referring to the appropriate information resource, and it immediately becomes on a par with the present. In other words, the time frame of the actual is arbitrarily extended, and the past, present and future (the future can be modeled with the help of modern prognostic tools) are just as arbitrarily rearranged.

It is clear that the computer not only transfers to some other point of the same space-time, but allows not only to enter another space, but also to re-create it, to build a new life plan.
What is the information society, in which, apparently, and we have to live?

The information society is a global economic, political, anthroposocial and technological project that involves a controlled civilization transition to a world social structure, in which the system of mass communications will play a dominant role in all areas of life. computer telecommunications technologies, in particular Internet technology.

The project, prognostic and scenic nature of the information society is manifested, in particular, in the formulation of national programs and concepts of transition to the information society, as well as programs for informatization of various sectors of activity, primarily science, education, management, politics, etc. $P$.

The concepts of the information society, for all their pragmatism and concreteness, are accentuated as utopias, anti-utopias and practicals (Alvin Toffler), i.e. orient themselves to a global ideal composed of the values of ecologism, humanism, anti-universalism, antitotalitarianism, pluralism, priority of the spiritual and cultural over utilitarian, civilizational.

The technological dependence of the information society does not exhaust the deep philosophical, social and socio-political meaning of this concept. The doctrine of the information society reflects the transition of civilization from the industrial to the postindustrial phase of development. The concept of "post-industrial society" was introduced by Bell (1973) 1, in accordance with the periodization scheme of the historical civilization social process, involving three 
stages: pre-industrial (agrarian), industrial and post-industrial.

Post-industrial society is characterized by the following features:

1. the reorientation of the economy from commodity production to service;

2. Determination of intellectual technologies in the technological and production spheres;

3. the decrease in the significance and fundamental nature of material ownership in the system of values;

4. increasing the importance of knowledge as the basis of technological and sociopolitical structures of society;

5. the shift of semantic and axiological accents in the structure of social organization;

6. reorganization of the cultural sphere, implying an imperative orientation to the priorities of intellectualism and the transformation of the ethics and morality of the individual, self-determined through the awareness of oneself as a producer of knowledge;

7. the emergence of the dominant "university" (education, science) as a system-generating social factor.

Just as an enterprise (firm) has been a key institution in the last hundreds of years thanks to its role in organizing the mass production of goods-things, the university, or some other form of institutionalizing knowledge will be a central institution for the next hundreds of years thanks to its role as a source of innovation and knowledge.

The third period (2000-2003) - the commercialization of web media - was accompanied by the so-called investment boom. It was characterized by a change in market conditions, in particular, a weakening of the political component of information activities and the arrival of commercial firms in the network. This period can be called the dotcom period, when the market saw an effective PR-tool on the Internet and began to actively sponsor its own Internet projects.

The expanded construction of dotcoms recruited both new networkers and old-timers to the network. As a positive result of this period, it should be noted not only that a wide consumer audience was accustomed to the network, which was able to obtain information about the necessary goods and services optimally and quickly, but also the fact that the skills of designers, coders and speechwriters.

Formed a community of professionals Internet publications. Specialized itself professional activity in the network. The distinctions between the language and the style of the Internet publication were published from publication in any other information channel.

Characteristic of this period is also the emergence of many professional consulting, design and programming firms. They were focused on the creation and maintenance of Internet projects, as well as the emergence of new markets, such as the domain name market.

Many analysts believe that the dot-com crisis is prevailed by the transition to a new economic and information model, which is integrated in the ideology of Web2.o services. Therefore, the fourth period of development of the Internet and Internet journalism can be called the period of Web2.0. Thus, it can be considered 
that the dotcom crisis created conditions for a new technological revolution in the network and a paradigm coup in the network interaction formats.

The fourth period of Web2.0 (2003 - to the present) is characterized by dramatic changes in terms of content, user and market. The term "Web2.0" coined by Tim O'Reilly. By this term it is simpler to understand everything as a certain combination of interactive services with a number of specific properties. Moreover, these properties can hardly be collected in a certain system. For example, the method of recognizing Web2.0 is explained in the article "25 facts about Web2.0", published in the magazine "Big City" in August 2006, as follows:

Various Internet services that have appeared on the list of broken dotcoms and based on the principles of collectivism, cooperation, openness, accessibility, interactivity can be called Web2.0, without fear that someone will accuse you of dilettantism. If any Internet service gets better due to the fact that more people use it, this is almost certainly Web2.0. If you are offered a lot of some great services, two gigabytes of memory, the most accurate map in the world and at the same time do not ask for any money for it - this is almost certainly Web2.o. If there are only amateur enthusiasts all around and there is not a single professional who receives a salary for this, then Web2.0 is also certain. If you can take and correct this article with your own hand - this is also probably Web2.o. If for the definition of a resource terms such as Ajax, RSS, AdSense, tags, blogs are used, it most likely has something to do with Web2.0.
In fact, O. Reilly carried out what is called rebranding in the $P R$ language, making the very concept of WEB the brand, and provided it with the property of versality. Thus, Web2.0 means that the network has changed significantly in relation to its original appearance. In other words, the network itself has become positioned as a product and as a brand. One hundred and only to implement the operation of naming, as many users actually saw the new phenomenon (Google, for example, contains more than 9.5 million links to Web2.0), and some producers of information resources and software immediately used it as a flag.

Web2.0 develops on the basis of integrations: the goals of the author and the reader societies of co-authors appear; roles of the author and reader in the functionality of the user; the goals of the producer and the user in the partner projects; roles of producer and user in the user's functionality; the possibility of creating and perceiving content in one tool; opportunities to work with the content and the ability to change the tool itself.

The ideology of Web2.0 is fundamentally oriented towards a horizontal system of relations and does not work in hierarchical structures. Web2.0 and the related concepts "Folksonomy", "Social Networks", "Blogs", etc., cannot be attributed solely to technological innovations. In fact, all this in one form or another has already been present in the global networks. It is rather a new ideology, not a technology. This, therefore, should not be about the possibilities of various network services, but about the perception of their audiences and nurturing on this widely and quickly mastered communicative soil of 
new forms of sociality and, possibly, political behavior.

However, volunteers armed with "smart" search programs can also take on analysis and expertise. So it is not clear why to study as a journalist if every housewife can manage information. The fears of professionals are understandable, since they feel that the center of informational activity is indeed shifting towards the Internet, where everyone can be a journalist to himself. In other words, work in a prestigious publication, identification with any media magnate today does not guarantee the success and popularity of a journalist. Consequently, the advance of amateurs through the Internet is a personal threat to the professional.

Such controversy really takes place, but the situation is not as pessimistic for professionals as it seems at first glance. It is just that what has acquired the name of the "professional revolution", in particular the transprofessionalization of journalistic activity, takes place. The emergence of Web2.0 allows for other reasons to construct a scheme for the periodization of the development of the Internet and, accordingly, Internet journalism: the emergence of the Internet as a means of self-expression and communication, amateur forms of addressing audiences (stage 1); the opening of the Internet as a media channel (stage 2); the opening of the Internet media as a business resource (stage 3 ); the emergence of social networks and other services Web2.0 (4th stage).

\section{REFERENCES}

1. Ferdig, R.E., Trammell, K.D. Content Delivery in the 'Blogosphere. //T.H.E.
Journal. 2004. - Электрон, ресурс. Режим доступа:

http://www.thejournal. com/magazine/vault/A4677D.cfm

2. Flew, T. New media: an introduction. Oxford; South Melbourne, Vic.: Oxford University Press, 2005

3. Gerbner, G. Ideological Perspectives and Political Tendencies in News Reporting //Journalism Quarterly. 1964. № 41. p. 495-506

4. Gillmor, D. We the Media. Grassroots Journalism by the People, for the People. //Oreilly.com — 2004. Электрон, ресурс. - Режим доступа: http://oreilly.com/ catalog/wemedia/book/index.csp

5. Gurak, L., Antonijevic S. Introduction: Weblogs, Rhetoric, Community and Culture. //Blogosphere. - 2004. Электрон, ресурс. - Режим доступа: http://blog.lib.umn.edu/blogosphere/i ntroduction.html

6. Herring, S. C., Kouper, I. Conversations in the blogosphere: An analysis 'from the bottom up. //Proceedings of the Thirty-Eighth Hawai'I International Conference on System Sciences. LoS Alamitos, California: IEEE Computer Society Press. 2005

7. Hewitt, H. Blog: Understanding the Information Reformation. - New York: Nelson Books. 2005. Электрон, ресурс. - Режим доступа: http://books. google.ru/books?id=Ifve I4ppjosC

8. Hypertext Terminology /Project «The Electronic Labyrinth» /C.Keep, T.McLaughlin, R.Parmar. - Электрон, ресурс. Режим доступа: 
http://www2.iat

h.virginia.edu/elab/hflo036.html

9. McQuail, D. Mass Communication Theory: an Introduction. London: Sage Publications, 1994

10. Molotch H., Lester M. News as Purposive Behavior, on the Strategic Use of Routine Events, Accidents \& Scandals. //American Sociological Review. 1974. - Vol. 39. -№ 1

11. Nardi B.A., Schiano, D.J, GumBrecht, $M$. Blogging as social activity. //Proceedings of Computer Supported Cooperative Work. 2004. - Электрон, ресурс. - Режим доступа: http://home.comcast.net/\%7Ediane.sch iano/CSC W04.Blog.pdf

12. Not Quite Samizdat: A Look at the Russian Blogosphere/Stephen Lock. 2007. Электрон, ресурс. - Режим доступа:

http://www.mmdcee.com/content/ rus/ReportENGBodylight.pdf

13. O'Reilly, T. Inventing the Future. //O'Reilly. - 04.09.2002. - Электрон, ресурс - Режим доступа: http://www.oreillynet.eom/pub/a/net work/2002/04/09/ fiiture.html 